\title{
A. HUBUNGAN PEMANFAATAN PERPUSTAKAANDENGAN HASIL BELAJAR SISWA DALAM MATA PELAJARAN FIKIH DI MAN 1 PADANGSIDIMPUAN
}

\author{
Rina Juliana
}

\begin{abstract}
:
Library utilization is one learning resource that can add insight and information for learners. The problem raised in this research is whether there is a correlation between the utilization of learning resources with students' learning result in the field of Jurisprudence study in MAN 1 Padangsidimpuan? The benefits to be achieved by researchers is for teachers to be able to utilize the library as one source of learning in improving student learning outcomes. The purpose of this research is to know the correlation between the utilization of learning resources with the students' learning result in the field of Jurisprudence study at MAN 1 Padangsidimpuan. To achieve this goal, this research uses quantitative approach and correlational research type. Technique of collecting data through questionnaire and documentation.

Validity test used pearson product moment correlation formula, while reliability test used alpha croanbach formula. To analyze the data used inferential descriptive method is by using simple correlation. The amount of correlation variable of library utilization with student learning result is 0,695 while contribution of variable $\mathrm{X} 1$ withY is $48,30 \%$ then rest $51,70 \%$ determined by other variable. Utilization of learning resources is closely related to student learning outcomes. This is because students have been able to identify, explore, investigate, guess, and finally find solusiterhadap problems that are given by teacher in field of fiqh study.
\end{abstract}

Keywords: Utilization, Learning Resources, Learning Outcomes 


\section{B. Pendahuluan}

Teliti dalam bekerja merupakan salah satu ciri profesionalitas. Demikan juga al-Qur'an menuntut manusia agar bekerja dengan penuh kesungguhan, apik, dan bukan asal jadi.

Dalam al-Qur'an surah Yusuf Allah berfirman:

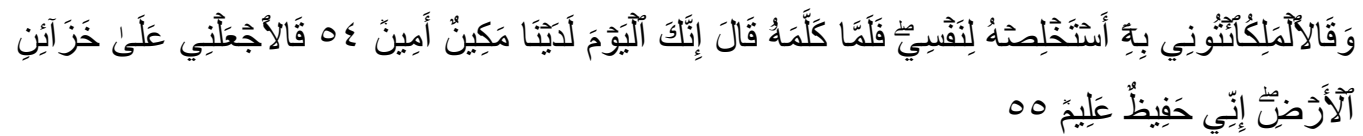

Artinya: Dan raja berkata: "Bawalah Yusuf kepadaKu, agar aku memilih Dia sebagai orang yang rapat kepadaku". Makatatkala raja telah bercakap-cakap dengan Dia, Dia berkata: "Sesungguhnya kamu (mulai) hari ini menjadi seorang yang berkedudukan Tinggi lagi dipercayai pada sisi kami". Berkata Yusuf: "Jadikanlah akubendaharawannegara (Mesir); Sesungguhnya aku adalah orang yang pandai menjaga, lagi berpengetahuan". ${ }^{1}$ QS. Yusuf: 54-55).

Menurut M. Quraish Shihab ayat di atas mendahulukan kata hafizh yang berati "pemelihara" daripada kata alim yang berarti "yang amat berpengetahuan" akan terdorong untuk meraih pengetahuan. Sejalan dengan itu menurut Ibnu Katsir hafiz itu berarti memelihara kepercayaan sedangkan alim berarti yang memiliki ilmu pengetahuan. ${ }^{2}$ Selanjutnya menurut Burhanuddin Abi al-Hasan bin Umar al-Biqai bahwa hafiz itu berarti memelihara atau menjaga apa yang diamanahkan kepadanya. ${ }^{3}$ Seseorang yang memlihara amanah dan tidak berpengetahuan akan terdorong untuk meraih pengetahuan yang belum dimilikinya. Sebaliknya, seseorang yang berpengetahuan tetapi tidak memiliki amanah, bisa jadi ia menggunakan pengetahuannya untuk mengkhianati amanah. Hal ini sama dengan QS. Al-Baqarah: 282 yang mendahulukan keadilan daripada pengetahuan tulis menulis utang piutang. Di sana dikemukakan bahwa hal itu agaknya disebabkan karena keadilan di samping menuntut adanya pengetahuan bagi yang akan berlaku adil, juga

${ }^{1}$ Departemen Agama RI, Al-Qur'an dan Terjemahannya, (Jakarta: Cahaya Intan Cemerlang, 2009), h. 242

${ }^{2}$ Ibnu Katsir, Tafsir al-Qur'an al-Azhim, jilid 2, (Beirut: Dar al-Fikr, 1992), h. 586

${ }^{3}$ Burhanuddin Abi al-Hasan bin Umar al-Biqai, Nazmu ad-Durari fi Tanasubi al-Ayati asSuwar, (Beirut: Dar al-Kutub al- Alamiah, 2003), h. 60 
karena seorang yang adil tetapi tidak mengetahui, keadilannya akan mendorong ia untuk belajar. Berbeda dengan yang mengetahui tetapi tidak adil. Ketika pengetahuannya akan digunakan untuk menutupi ketidakadilannya, ia akan mencari cela hukum untuk membenarkan penyelewengan dan menghindarkan sanksi. ${ }^{4}$

Dengan demikian ayat itu secara implisit menyatakan pentingnya profesionalitas, bahwa Yusuf menawarkan dirinya bekerja sesuai dengan kemampuan yang dimilikinya. Sebab jika tidak, ia khawatir tidak mampu menjalankan tugasnya dengan baik.

Salah satu faktor yang mempengaruhi hasil belajar siswa adalah guru. Guru yang dituntut di siniadalah guru yang memiliki kompetensi salahsatunya kompetensi profesional. Salah satu contoh guru yang professional adalah dapat memanfatakan sumber belajar dengan baik, salah satunya perpustakaan. Menurut UU Nomor 14 Tahun 2005 tentang Guru dan Dosen Pasal 1: "Guru adalah pendidik professional dengan tugas utama mendidik, mengajar, membimbing, mengarahkan, melatih, menilai, dan mengevaluasi peserta didik pada pendidikan anak usia dini jalur pendidikan formal, dasar, dan menengah. ${ }^{5}$

Hasil belajar merupakan proses dalam diri individu yang berinteraksi dengan lingkungan untuk mendapatkan perubahan dalam perilakunya. Perubahan itu diperoleh melalui usaha (bukan karena kematangan), menetap dalam relatif lama dan merupakan hasil pengalaman.Hasil belajar juga merupakanmanifestasi perubahan baik ranah kognitif, afektif, dan psikomotor setelah proses pembelajaran berlangsung. Perpaduan antara ketiga hal tersebut melahirkan kompetensi siswa. Kompetensi yang dimiliki siswa dapat dilihat dari kesanggupannya untuk menyelesaikan tugas-tugas yang dibebankan kepadanya.

\footnotetext{
${ }^{4}$ M. Quraish Shihab, Tafsir al-Misbah: Pesan, Kesan, dan Keserasian al-Qur'an, Volume: 6, (Jakarta: Lentera Hati, 2004), h. 484

${ }^{5}$ Undang-Undang RI Nomor 14 Tahun 2005 Tentang Guru dan Dosen, (Jakarta: Sinar Grafika, 2008), h. 5
} 
Sumber belajar dapat dirumuskan sebagai segala usaha yang dapat memberikan kemudahan belajar, sehingga diperoleh sejumlah informasi, pengetahuan, pengalaman, dan keterampilan yang diperlukan. ${ }^{6}$ Sarana dan prasarana yang memadai akan sangat membantu proses pembelajaran. Manfaat sumber belajar bergantung kepada kompetensi guru dan siswa untuk berkomunikasi dan berinteraksi dengan pesan yang terkandung dalam sumber pembelajaran yang didayagunakan.Untuk dapat memecahkan masalah tersebut maka pemanfataan perpustakaan sangat diperlukan.

Berdasarkan pengamatan yang dilakukan bahwa di MAN 1 Padangsidimpuan terlihat bahwa perlengkapan perpustakaan sebagai salah satu sumber belajar di sekolah tidak terawat dengan baik dan guru juga jarang menggunakannya. Guru tidak dapat memanfaatkan perpustakaan tersebut karena kurang terampil untuk memanfaatkannya, sehingga para siswa juga kurang mampu dalam memanfaatkan sumber belajar. ${ }^{7}$ Perpustakaan seharusnya mendapat perhatian yang besar dari kepala sekolah, karena kelengkapan dan kenyamanan sebuah perpustakaan sekolah akan mendatangkan pembaca yang haus akan informasi dan ilmu pengetahuan. Dalam hal ini guru juga memiliki peranan penting untuk memotivasi siswa agar dapat memanfaatkan sumber belajar yang ada.

Dengan demikian, persoalan-persoalan tersebut masih membutuhkan jawaban, dimana adanya kesenjangan antara hasil belajar dengan strategi pembelajaran pemecahan masalah dan pemanfaatan perpustakaan di MAN 1 Padangsidimpuan. Seharusnya dengan adanya strategi pemecahan masalah yang baik dan guru dapat memotivasi siswa untuk dapat memanfaatkan sumber belajar agar siswa dapat mendayagunakannya dengan baik dan ini akan berimplikasiterhadap peningkatan hasil belajar siswa khususnya dalam bidang studi fikih, tetapi realitanya masih banyak hasil belajar siswa yang belum

\footnotetext{
${ }^{6}$ Jejen Musfah, Peningkatan Kompetensi Guru Melalui Pelatihan dan Sumber Belajar Teori dan Praktik, (Jakarta: Kencana, 2011), h. 101

${ }^{7}$ Observasi dilakukan pada hari Jum'at tanggal 27 November 2015, pukul 09.00 WIB di MAN 1 Padangsidimpuan.
} 
tuntas.Berdasarkan hal demikian maka jelas ada masalah yaitu adanya kesenjangan antara teori dan fakta. Berdasarkan uraian di atas maka penulis ingin meneliti tentang "Hubungan Pemanfaatan Perpustakaan Dengan Hasil Belajar Siswa Bidang Studi Fikih di MAN 1 Padangsidimpuan.

\section{LandasanTeori}

\section{Pemanfaatan Perpustakaan}

Perpustakaan berasal dari kata pustaka. Dalam Kamus Besar Bahasa Indonesia pustaka berarti kitab, buku. Setelah mendapat aalan per dan akhiran an menjadi perpustakaan yang berarti koleksi bahan pustaka. Dalam bahasa Inggris perpustakaan dikenal dengan istilah library. Istilah ini berasal dari kata Latin liber atau libri yang berarti buku. Dari kata Latin tersebut terbentuklah istilah librarius yang artinya tentang buku.

Dengan demikian, batasan perpustakaan ialah sebuah ruangan, bagian sebuah gedung, ataupun gedung itu sendiri yang digunakan untuk menyimpan buku dan terbitan lainnya yang biasanya disimpan menurut tata susunan tertentu untuk digunakan pembaca, bukan untuk dijual. ${ }^{8}$

Defenisi di atas menunjukkan bahwa koleksi perpustakaan digunakan untuk pembaca. Selanjutnya perpustakaan bertujuan untuk mendayagunakan koleksinya untuk kepentingan pembaca.

Secara umum perpustakaan mempunyai arti sebagai suatu tempat yang di dalamnya terdapat kegiatan pemghimpunan, pengolahan, dan penyebarluasan (pelayanan) segala macam informasi, baik yang tercetak maupun yang terekam dalam berbagai media seperti buku, majalah, surat kabar, film, kaset, tape recorder, video, komputer, dan lain-lain. Semua koleksi informasi tersebut disusun berdasarkan sistem tertentu dan dipergunakan untuk kepentingan belajar melalui kegiatan membaca dan mencari informasi bagi segenap masyarakat yang membutuhkannya. ${ }^{9}$

\footnotetext{
${ }^{8}$ Sulistyio Basuki, Pengantar Ilmu Perpustakaan, (Jakarta: Gramedia Pustaka Utama, 1991), h. 3

${ }^{9}$ SutarnoNS, Manajemen Perpustakaan Suatu Pendekatan Praktik, (Jakarta: Sagung Seto, 2006), h. 11
} 
Selanjutnya menurut organisasi International Federation of Library Associations and Institutions (IFLA) mendefenisikan perpustakaan sebagai kumpulan materi tercetak dan media noncetak atau sumber informasi dalam komputer yang disusun secara sistematis untuk digunakan pemakai. ${ }^{10}$ Dengan demikian defenisi perpustakaan selalu mencakup unsur koleksi, penyimpanan, dan pemakai.

Selanjutnya sebuah perpustakaan memnuhi persyaratan tertentu yaitu:

a. Adanya kumpulan buku-buku dan bahan pustaka lainnya, baik tercetak, terekam, maupun dalam bentuk lain sesuai perkembangan ilmu pengetahuan dan teknologi.

b. Koleksi tersebut di atas menurut suatu sistem tertentu, diolah/diproses meliputi registrasi dan identifikasi, klasifikasi, katalogisasi, dan dilengkapi dengan perlengkapan koleksi, seperti slip buku, kartu-kartu katalog, kantong buku dan lain sebagainya. Koleksi itu tidak sekedar ditumpuk, sehingga terkesan seperti gudang buku.

c. Semua sumber informasi ditempatkan di gedung atau ruangan tersendiri, dan sebaiknya tidak disatukan dengan kantor atau kegiatan yang lain.

d. Perpustakaan semestinya dikelola atau dijalankan oleh petugas-petugas, dengan persyaratan tertentu yang melayani pemakai dengan sebaikbaiknya.

e. Ada masyarakat pemakai perpustakaan tersebut, baik untuk membaca, meminjam, meneliti, menggali, menimba, dan mengembangkan ilmu pengetahuan yang diperoleh di perpustakaan, sehingga perpustakaan sering disebut sebagai gudang ilmu.

f. Perpustakaan merupakan institusi yang perlu bermitra dengan lembaga yang berkaitan dengan proses penyelenggaraan pendidikan secara langsung dan tidak langsung, baik formal maupun nonformal. ${ }^{11}$

\section{Tujuan Perpustakaan}

\footnotetext{
${ }^{10}$ Sulistyio Basuki, op.cit., h. 4

${ }^{11}$ SutarnoNS, op.cit., h. 13
} 
Tujuan didirikannya perpustakaan sekolah tidak terlepas dari tujuan diselenggerakannya pendidikan sekolah secara keseluruhan, yaitu untuk memberikan bekal kemampuan dasar kepada peserta didik. Berdasarkan hal tersebut Allah berfirman dalam surah Al-Alaq Ayat 1-5:

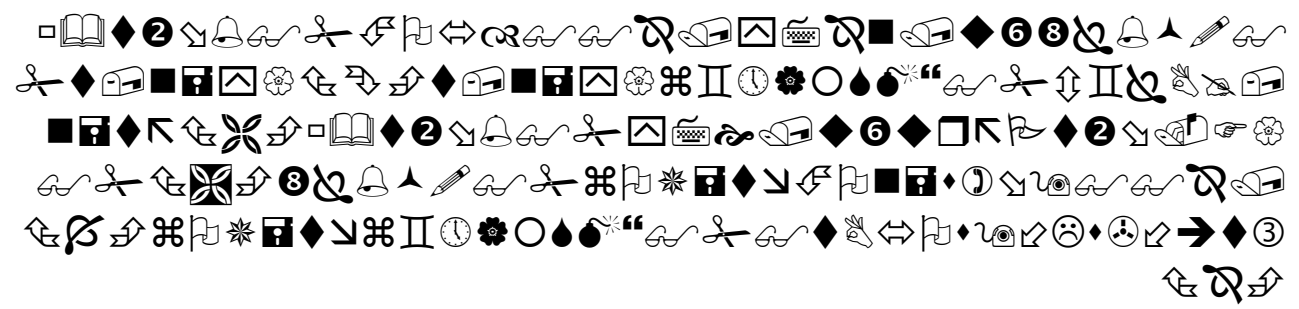

Artinya: Bacalah dengan (menyebut) nama Tuhanmu yang Menciptakan,, Diatelahmenciptakanmanusiadarisegumpaldarah., Bacalah, danTuhanmulah yang Maha pemurah, yang mengajar (manusia) dengan perantaran kalam, Dia mengajar kepada manusia apa yang tidak diketahuinya

Pada ayat ketiga dijelaskan bahwa Allah menyuruh manusia untuk menulis dengan qalam. Allah menyebutkan dengan perintah tulislah, maka hendaklah ia menulis sampai hari kiamat. ${ }^{12}$ Menurut Muhammad Abduh sebagaimana yang dikutip Hamka kelima ayat di atas merupakan penilaian yang tertinggi tentang kepandaian membaca dan menulis. Beliau menyebutkan dalam tafsirnya "tidak didapat kata-kata yang lebih mendalam dan alasan yang lebih sempurna daripada ayat tersebut di dalam menyatakan kepentingan membaca dan menulis ilmu pengetahuan dalam segala cabang dan bahagiannya". ${ }^{13}$

Al-Qur'an juga disebutkan bahwa permulaan turunnya wahyu, Allah memerintahkan agar mampu membaca. Sebagai sumber informasi, maka perpustakaan berperan penting dalam meningkatkan minat baca dan mewajibkan membaca. Karena dengan membaca seseorang memperoleh ilmu pengetahuan. Perpustakaan sekolah sebagai bagian integral dari sekolah, 1996), h. 420

${ }^{12}$ Muhammad Abdul Qadir Atha', Ahkam al-Qur'an, (Beirut: Dar-al-Kutub al-Alamiyah,

${ }^{13}$ Hamka, Tafsir al-Azhar, juz XXX, (Jakarta: Pustaka Panjimas, 1996), h. 145 
merupakan komponen utama pendidikan di sekolah, diharapkan dapat menunjang terhadap pencapaian tujuan tersebut.

Sejalan dengan hal di atas, maka tujuan perpustakaan sekolah adalah sebagai berikut:

a. Mendorong dan mempercepat proses penguasaan teknik membaca siswa

b. Membantu menulis kreatif bagi para siswa dengan bimbingan guru dan pustakawan

c. Menumbuhkembangkan minat dan kebiasaan membaca para siswa

d. Menyediakan berbagai macam sumber informasi untuk kepentingan pelaksanaan kurikulum

e. Mendorong, menggairahkan, memelihara, dan memberi semangat membaca dan semangat belajar bagi para siswa

f. Memperluas, meperdalam, dan memperkaya pengalaman belajar para siswa dengan membaca buku dan koleksi lain yang mengandung ilmu pengetahuan dan teknologi, yang disediakan oleh perpustakaan

g. Memberikan hiburan sehat untuk mengisi waktu senggang melalui kegiatan membaca, khususnya buku-buku dan sumber bacaan lain yang bersifat kreatif dan ringan, seperti fiksi, cerpen, dan lainnya. ${ }^{14}$

Dalam tujuan tersebut tergambar dengan jelas arah dan capaian yang dimaksudkan dalam penyelenggaraan perpustakaan sekolah, yang dalam jangka panjangnya adalah untuk menambah dasar-dasar pengetahuan untuk menjadi pondasi bagi perkembangan selanjutnya. Dan semua itu, mengacu kepada pelaksanan membangun jangka panjang negara kita yang lebih menitikberatkan kepada peningkatan kualitas sumber daya manusia.

\section{Fungsi Perpustakaan}

Perpustakaan sekolah mempunyai empat fungsi umum yaitu sebagai berikut:

a. Fungsi edukatif

Maksudnya secara keseluruhan segala fasilitas dan sarana yang ada pada perpustakaan sekolah, terutama koleksi yang dikelolanya banyak membantu para siswa sekolah untuk belajar dan memperoleh kemampuan dasar dalam mentransfer konsep-konsep pengetahuan, sehingga di

\footnotetext{
${ }^{14}$ Pawit M. Yusuf dan Yaya Suhendar, Pedoman Penyelenggaraan Perpustakaan Sekolah, (Jakarta: Kencana, 2005), h. 3
} 
kemudian hari para siswa memiliki kemampuan untuk mengembangkan dirinya lebih lanjut. Fungsi ini erat kaitannya dengan pembentukan manusia pembangunan yang berkualitas di masa yang akan datang. Pendidikan memang merupakan salah satu cara yang paling tepat untuk meningkatkan kualitas manusia seutuhnya.

b. Fungsi informatif

Fungsi ini berkaitan dengan mengupayakan penyediaan koleksi perpustakaan yang bersifat "memberi tahu" akan hal-hal yang berhubungan dengan kepentingan para siswa dan guru. Melalui membaca berbagai media bahan bacaan yang disediakan oleh perpustakaan sekolah, para siswa dan guru. Melalui membaca berbagai media bahan bacaan yang disediakan oleh perpustakaan sekolah, para siswa dan guru akan banyak tahu tentang segala hal yang terjadi di dunia ini.

\section{c. Fungsi kreasi}

Fungsi rekreasi ini memang bukan yang utama dari dibangunnya perpustakaan sekolah, namun hanya sebagai pelengkap saja guna memenuhi kebutuhan sebagian anggota masyarakat sekolah akan hiburan intelektual. Bahkan meskipun bukan yang utama, namun sangat penting kedudukannya bagi upaya peningkatan kesadaran intelektual dan pembangunan inspirasi. Pada pelaksanaannya orang tidak mungkin harus berhadapan dengan buku atau bahan bacaan lain yang lebih serius dan sedikit memusingkan. Adakalanya mereka menginginkan bahan bacaan yang ringan dan bersifat menghibur seperti misalnya buku-buku cerita dan surat kabar.

d. Fungsi riset

Fungsi ini maksudnya adalah koleksi perpustakaan sekolah bisa dijadikan bahan untuk membantu dilakukannya kegiatan penelitian sederhana. Segala jenis informasi tentang pendidikan setingkat sekolah yang bersangkutan sebaiknya disimpan di perpustakaan ini sehingga 
dengan demikian jika ada peneliti yang ingin mengetahui tentang informasi tersebut tinggal membacanya di perpustakaan. Terutama sekali ini dilakukan guna menunjang kegiatan penelitian pustaka. ${ }^{15}$

\section{Tugas/Kegiatan Perpustakaan}

Sesuai dengan pengertian perpustakaan sekolah yang berintikan tiga kegiatan utama yaitu kegiatan penghimpunan, pengolahan, dan penyebarluasan segala macam informasi pendidikan kepada para siswa dan guru, maka secara gamblang perpustagaan sekolah bertugas sesuai dengan tugas inti tersebut, yaitu:

a. Menghimpun atau mengumpulkan, mendayagunakan, memlihara, dan membina secara terus menerus bahan koleksi atau sumber informasi (bahan pustaka) dalam bentuk apa saja, seperti misalnya, buku, majlah, surat kabar, dan jenis koleksi lainnya.

b. Mengolah sumber informasi tersebut dengan menggunakan sistem dan cara tertentu, sejak dari bahan-bahan tersebut datang ke perpustakaan sampai pada siap disajikan atau dilayankan kepada para penggunanya yakni para siswa dan guru di lingkungan sekolah yang bersangkutan. Kegiatan ini antara lain meliputi pekerjaan penginventarisasian, pengklasifikasian, atau penggolongan koleksi, pengkatalogan, pelabelan, pembuatan alat pinjam, dan lain-lain.

c. Menyebarluaskan sumber informasi atau bahan-bahan pustaka kepada segenap anggota yang membutuhkannya sesuai dengan kepentingannya yang berbeda dengan yang lainnya. Termasuk dalam kegiatan ini adalah pelayanan referensi dan informasi, pelayanan peminjaman koleksi, pelayanan promosi, pelayanann bimbingan kepada pembaca, dan sebagainya termasuk pelayanan kepada para siswa dan guru dalam rangka mencari informasi yang berkaitan dengan bidang minatnya.

\footnotetext{
${ }^{15}$ Ibid., h. 44-45
} 


\section{Pemanfataan Perpustakaan Sebagai Sumber Belajar}

Perpustakaan sekolah sebagai salah satu sarana pendidikan penunjang kegiatan belajar siswa memegang peranan yang sanagt penting dalam memacu tercapainya tujuan pendidikan di sekolah. Dalam Undang-undang Sistem Pendidikan Nasional (UU No. 2 Tahun 1989), sarana penunjang proses kegiatan belajar mengajar dinamakan "sumber daya pendidikan". Kalau disimak pasal yang menyangkut eksistensi perpustakaan yaitu pasal 35, disebutkan bahwa "Setiap satuan pendidikan jalur pendidikan sekolah yang diselenggarakan oleh pemerintah maupun masyarakat harus menyediakan sumber belajar". Pada penjelasan selanjutnya dinyatakan antara lain: "Pendidikan tidak mungkin terselenggara dengan baik bila para tenaga kependidikan maupun para peserta didik tidak didukung oleh sumber belajar yang diperlukan untuk penyelenggaraan kegiatan belajar-mengajar yang bersangkutan. Salah satu sumber belajar yang mata penting, tetapi bukan satu-satunya adalah perpustakaan. ${ }^{16}$

Selanjutnya Berdasarkan Peraturan Pemerintah Nomor 19 Nomor 19 Tahun 2005 tentang Standar Nasional Pendidikan Pasal 42 ayat 1 dinyatakan bahwa, setiap astuan pendidikan wajib memiliki sarana yang meliputi perabot, peralatan pendidikan, media pendidikan, buku, dan sumber belajar lainnya, bahan habis pakai, serta perlengkapan lain yang diperlukan untuk menunjang proses pembelajaran yang teratur dan berkelanjutan. ${ }^{17}$

Pada ayat 2 dinyatakan, setiap satuan pendidikan wajib memiliki prasarana yang meliputi lahan, ruang kelas, ruang pimpinan satuan pendidikan, ruang pendidik, ruang tata usaha, ruang perpustakaan, ruang laboratorium, ruang bengkel kerja, ruang unit produksi, ruang kantin, instalasi daya dan jasa, tempat berohlaga, tempat beribadah, tempat bermain,

${ }^{16}$ Darmono, Manajemen dan Tata Kerja Perpustakaan Sekolah, (Jakarta: Grasindo, 2004), h. 1

${ }^{17}$ Peraturan Pemerintah Nomor 19 Nomor 19 Tahun 2005 tentang Standar Nasional Pendidikan Pasal 42 ayat 1 
tempat rekreasi, dan ruang/tempat lain yang diperlakukan untuk menunjang proses pembelajaran yang teratur dan berkelanjutan.

Jika dilihat dari penjelasan tersebut, hakikat perpustakaan sekolah adalah pusat sumber belajar dan sumber informasi bagi pemakainya. Perpustakaan dapat pula diartikan sebagai kumpulan buku-buku atau tempat buku dihimpun dan diorganisasikan sebagai media belajar siswa.

Selanjutnya menurut Wafford sebagaimana yang dikutip Darmono menerjemahkan perpustakaan sebagai salah satu organisasi sumber belajar yang menyimpan, mengelola, dan memberikan layanan bahan pustaka baik buku maupun non buku kepada masyarakat tertentu maupun masayarakat umum. $^{18}$

Perpustakaan sekolah adalah perpustakaan yang tergabung pada sebuah sekolah, dikelola sepenuhnya oleh sekolah yang bersangkutan dengan tujuan utama membantu sekolah untuk mencapai tujuan khusus sekolah dan tujuan pendidikan pada umumnya. ${ }^{19}$

Dengan demikian perpustakaan sekolah merupakan bagian integral dari program sekolah secara keseluruhan, dimana bersama-sama dengan komponen pendidikan lainnya turut menentukan keberhasilan proses pendidikan dan pengajaran. Melalui perpustakaan siswa dapat mendidik dirinya secara berkesinambungan.

\section{Hasil Belajar}

Hasil belajar dapat dijelaskan dengan memahami dua kata yang membentuknya, yaitu " hasil” dan " belajar”. Pengertian hasil menunjuk pada suatu perolehan akibat dilakukannya suatu aktivitas atau proses yang mengakibatkan berubahnya input secara fungsional.Belajar dilakukan untuk mengusahakan adanya perubahan perilaku pada individu yang belajar. Perubahan perilaku itu merupakan perolehan yang menjadi hasil belajar. Belajar itu merupakan perubahan perilaku sebagai hasil dari pengalaman.

\footnotetext{
${ }^{18}$ Ibid.,h. 2

${ }^{19}$ Sulistyio Basuki, op.cit., h. 50-51
} 
Belajar yang sebaik-baiknya adalah dengan mengalami sesuatu yaitu menggunakan pancaindra. Dengan kata lain, bahwa belajar adalah suatu cara mengamati, membaca, meniru, mengintisimasi, mencoba sesuatu, mendengar dan mengikuti arah tertentu. ${ }^{20}$ Dengan demikian hasil belajar adalah perubahan yang mengakibatkan manusia berubah dalam sikap dan tingkah lakunya. $^{21}$

Di dalam al-Qur'an kata hasil belajar tersebar dalam beberapa surah seperti kata al-inba', al-hisab, al-wazn, al-bala', al-wazn, al-taqdir, dan annadzr.Kata al-inba' terdapat dalam surat al-Baqarah ayat 31 dan 33, Allah berfirman:

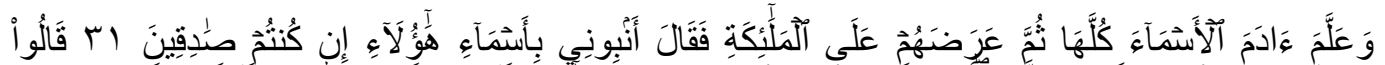

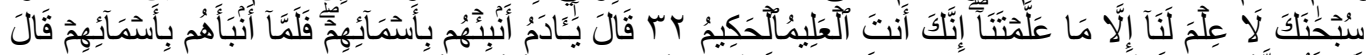

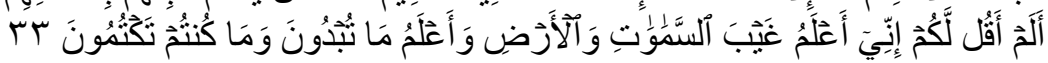

Artinya: Dan Dia mengajarkan kepada Adam Nama-nama (benda-benda) seluruhnya, kemudian mengemukakannya kepada Para Malaikat lalu berfirman: "Sebutkanlah kepada-Ku nama benda-benda itu jika kamu mamang benar orang-orang yang benar!" Mereka menjawab: "Maha suci Engkau, tidak ada yang Kami ketahui selain dari apa yang telah Engkau ajarkan kepada kami; Sesungguhnya Engkaulah yang Maha mengetahui lagi Maha Bijaksana."Allah berfirman: "Hai Adam, beritahukanlahkepadamereka Nama-namabendaini." Makasetelahdiberitahukannyakepadamereka Namanamabendaitu, Allah berfirman: "Bukankahsudah Ku katakankepadamu, bahwaSesungguhnyaakumengetahuirahasialangitdanbumidanmengetahuiapa yang kamulahirkandanapa yang kamusembunyikan?"

Ayat ini menurut Quraish sihab menginformasikan bahwa manusia dianugrahi Allah potensi untuk mengetahui nama atau fungsi dan karakter setiap benda-benda misalnya fungsi api, fungsi angin dan sebagainya. Dia juga dianugerahi potensi untuk berbahasa. Sistem pengajaran bahasa kepada manusia (anak kecil) bukan dimulai dengan mengajarkan kata kerja tetapi mengajarkannya terlebih dahulu nama-nama. Itulah sebagian makna yang dipahami oleh para ulama. Selanjutnya beliau mengemukakan bahwa

\footnotetext{
${ }^{20}$ YatimRiyanto, ParadigmaBaruPembelajaran: SebagaiReferensiBagi Guru PendidikdalamImplementasiPembelajaran Yang Efektif Dan Berkualitas,(Jakarta: Kencana, 2009), h. 5

${ }^{21}$ Ibid., h. 44-45
} 
keistimewaan manusia adalah kemampuannya mengekspresikan apa yang terlintas dalam benaknya serta kemampuannya menangkap bahasa, sehingga ini menghantarkannya "mengetahui". Di sisi lain, kemampuan manusia merumuskan ide dan memberi nama bagi segala sesuatu merupakan langkah menuju terciptanya manusia berpengetahuan dan lahirnya ilmu pengetahuan. ${ }^{22}$ Menurut Imam as-Suyuti ayat di atas menjelaskan bahwa Allah telah mengajarkan kepada Adam nama-nama semua makhluk ciptaanNya seperti manusia, hewan, bumu, lautan, gunung, dan lain sebagainya. ${ }^{23}$

Untuk mengetahui hasil belajar siswa maka hal yang harus dilakukan guru adalah dengan melakukan penilaian pembelajaran. Sehubungan dengan penilaian pembelajaran Moekijat sebagaimana yang dikutip E. Mulyasa mengemukakan teknik penilaian pembelajaran yang mencakup aspek pengetahuan, keterampilan, dan sikap sebagai berikut:

a. Penilaian belajar pengetahuan dapat dilakukan denga ujian tulis, lisan, dan daftar isian pertanyaan.

b. Penilaian belajar keterampilan dapat dilakukan dengan ujian praktek, analisis keterampilan dan analisis tugas, serta penilaian oleh peserta didik sendiri.

c. Penilaian belajar sikap dapat dilakukan dengan daftar isian sikap dari diri sendiri, daftar isian sikap yang disesuaikan dengan tujuan program, dan skala deferensial sematik. ${ }^{24}$

Menurut Santrock seorang ahli Psikologi Pendidikan, kecerdasan adalah kemampuan. Dalam porsi yang lebih humanis, Gardner menyebutkan bahwa kemampuan adalah pemecahan masalah dan kreativitas. Definisi kecerdasan jika dikembangkan dalam kebudayaan manusia adalah kemampuan memecahkan masalah dan menciptakan

\footnotetext{
${ }^{22}$ M. Quraish Shihab, Tafsir al-Misbah: Pesan, Kesan, dan Keserasian al-Qur'an, Volume: 1, (Jakarta: Lentera Hati, 2004), h. 143-144

${ }^{23}$ Imam Jalaluddin Abdurrahman bin Abi Bakr as-Suyuthi, Ad-Durru al-Mantsur fi Tafsir alMa'tsur, (Beirut: Dar-al-Kutub al-'Alamiyah, 2000), h. 101

${ }^{24}$ Ibid., h. 213
} 
produk yang bernilai budaya. Sebuah definisi yang diperkenalkan pertama oleh Howard Gardner pada tahun 1983 melalui bukunya yang terkenal, Frames of Mind. ${ }^{25}$

\section{Hasil dan Pembahasan Penelitian}

\section{Hasil Penelitian}

Untuk melakukan pengujian hipotesis yang diajukan dalam penelitian ini, sebagaimana yang diolah menggunakan rumus korelasi sederhana. Dalam kajian teoritis yang dilakukan pada bagian terdahulu, penulis mempunyai dugaan yang kuat bahwa "Terdapat Hubungan Pemanfaatan Perpustakaan dengan Hasil Belajar Siswa dalam Mata Pelajaran Fikih di MAN 1 Padangsidimpuan”

Koefisien korelasi antara strategi pembelajaran pemecahan masalah terhadap hasil belajar dalam bidang studi fikih di MAN 1 Padangsidimpuan sebesar 0,695. Untuk menguji hipotesis, maka nilai $r$ hitung $\left(r_{\mathrm{xy}}\right)$ dikonsultasikan kepada $\mathrm{r}$ tabel $\left(\mathrm{r}_{\mathrm{t}}\right)$, yaitu $\mathrm{N}-\mathrm{nr}=91-2=89$. Pada tabel " $\mathrm{r}$ " Product Moment ditemukan nilai $r$ tabel $\left(r_{t}\right)$ untuk $\mathrm{df}=89$ pada tingkat kepercayaan $5 \%$ sebesar 0,213. Dengan demikian hipotesis yang berbunyi "terdapat hubungan pemanfataan perpustakaan terhadap hasil belajar dalam bidang studi fikih di MAN 1 Padangsidimpuan"diterima karena $r$ hitung $\left(r_{x y}=0,695>r_{t}=0,213\right)$. Artinya semakin banyakpemanfataan perpustakaan yang dilakukan siswamakaakan semakin baik hasil belajar siswa di MAN 1 Padangsidimpuan.

\section{PembahasanPenelitian}

Penelitian berjudul tentang hubungan pemanfaatan perpustakaan terhadap hasil belajar siswa dalam mata pelajaran fikih di MAN 1 Padangsidimpuan merupakan salah satu penelitian yang bertujuan untuk menguji kebenaran teori terhadap kondisi yang terjadi di lapangan dengan menggunakan rumus statistic atau yang dikenal dengan jenis penelitian kuantitatif. Penulis tertarik mengangkat judul penelitian tersebut dilatarbelakangi untuk menguji sebuah

\footnotetext{
${ }^{25}$ Ibid., h. 161-162
} 
teori. Teori ini direduksi dalam konteks pembelajaran di MAN 1 Padangsidimpuan, akan tinggi.

Ditemukan pemanfataan perpustakaan berpengaruh secara signifikan terhadap hasil belajar siswa. Menurut AECT (Association for Education and Communication Technology) bahwa sumber belajar adalah semua sumber, baik berupa data, orang, wujud tertentu yang dapat digunakan oleh siswa dalam belajar, baik secara terpisah maupun secara terkombinasi sehingga mempermudah siswa dalam mencapai tujuan belajar atau mencapai kompetensi tertentu. Salah satu sumber belajar yang dapat mempengaruhi hasil belajar siswa adalah pemanfaatan perpustakaan.

Dalam mengoptimalkan pemanfaatan perpustakaan dalam memecahkan permasalahan pembelajaran ada beberapa hal yang harus diperhatikan, di antaranya: masalah pembelajaran yang dihadapi siswa, pemanfataan perpustakaan yang dilakukan siswa dan guru untuk menjawab permasalahan pembelajaran tersebut, hal-hal apa saja yang harus dilakukan siswa dan guru dalam memanfataan perpustakaan.

Perpustakaan merupakan sebagai kumpulan materi tercetak dan media noncetak atau sumber informasi dalam komputer yang disusun secara sistematis untuk digunakan pemakai. Tujuan didirikannya perpustakaan sekolah tidak terlepas dari tujuan diselenggerakannya pendidikan sekolah secara keseluruhan, yaitu untuk memberikan bekal kemampuan dasar kepada peserta didik. Perpustakaan sekolah sebagai bagian integral dari sekolah, merupakan komponen utama pendidikan di sekolah, diharapkan dapat menunjang terhadap pencapaian tujuan tersebut.

Dengan demikian pemanfataan perpustakaan juga berpengaruh terhadap hasil belajar sebab dengan dimanfatakannya perpustakaan dapat membantu siswa dalam mempelajari sesuatu. Segala informasi yang didapat dari pemanfataan perpustakaan sebagai salah satu sumber belajar.

\section{E. Penutup}




\section{Kesimpulan}

Pemanfataan perpustakaan berhubungan secara signifikan dengan hasil belajar siswa. Besarnya hubungan variabel pemanfataan perpustakaan terhadap hasil belajar siswa adalah 0,695 sedangkan kontribusi variabel X1 terhadap Y sebesar 48,30\% kemudian sisanya 51,70\% ditentukan oleh variabel lain. Informasi ini memberikan keterangan bahwa variabel pemanfataan memberikan hubungan kuat terhadap hasil belajar siswa.

\section{Saran-Saran}

Data empiris telah membuktikan bahwa strategi pembelajaran pemecahan masalah dan pemanfaatan pemanfataan perpustakaan dapat meningkatkan hasil belajar siswa dalam mata pelajaran Fikih di MAN 1 Padangsidimpuan. Dalam hal ini ada beberapa saran yang dapat peneliti ajukan:

a. Kepada siswa diharapkan untuk lebih aktif dan giat, agar criteria ketuntasan minimal yang ditetapkan dapat tercapai dalam mata pelajaran Fikih.

b. Kepada para guru bidang studi Fikih agar dapat memanfaatkan perpustakaan dengan baik sebab perpustakaan merupakan salah satu sumber belajaryang diharapkan dapat meningkatkan hasil belajar siswa.

c. Kepada para siswa dan siswi di MAN 1 Padangsidimpuan agar dapat memanfaatkan perpustakaan dengan baik sebab perpustakaan merupakan salah satu sumber belajaryang diharapkan dapat meningkatkan hasil belajar.

d. Kepada kepala Sekolah MAN 1 Padangsidimpuan diharapkan dapat membekali dan menambah pengetahuan para guru dan siswa tentang pemanfataan perpustakaan yang baik.

e. Kepada peneliti ada kemungkinan kelemahan yang terjadi dalam pelaksanaan penelitian ini, maka perlu kiranya diadakan penelitian lebih lanjut dengan memperbesar objek penelitian. 
f. Begitu juga dengan peneliti yang berminat untuk meneliti lebih lanjut masalah dalam penelitian ini supaya memperhatikan variabel lain yang mungkin turut berhubungan terhadap hasil belajar siswa.

\section{F. DaftarPustaka}

Departemen Agama RI, Al-Qur'an dan Terjemahannya, (Jakarta: Cahaya Intan Cemerlang, 2009.

Ibnu Katsir, Tafsir al-Qur'an al-Azhim, jilid 2, Beirut: Dar al-Fikr, 1992.

Burhanuddin Abi al-Hasan bin Umar al-Biqai, Nazmu ad-Durari fi Tanasubi alAyati as-Suwar, Beirut: Dar al-Kutub al- Alamiah, 2003.

M. Quraish Shihab, Tafsir al-Misbah: Pesan, Kesan, dan Keserasian al-Qur'an, Volume: 6, Jakarta: Lentera Hati, 2004.

Undang-Undang RI Nomor 14 Tahun 2005 Tentang Guru dan Dosen, Jakarta: Sinar Grafika, 2008.

Jejen Musfah, Peningkatan Kompetensi Guru Melalui Pelatihan dan Sumber Belajar Teori dan Praktik, Jakarta: Kencana, 2011.

Sulistyio Basuki, Pengantar Ilmu Perpustakaan, Jakarta: Gramedia Pustaka Utama, 1991.

Sutarno NS, Manajemen Perpustakaan Suatu Pendekatan Praktik, Jakarta: Sagung Seto, 2006.

Muhammad Abdul Qadir Atha', Ahkam al-Qur'an, Beirut: Dar-al-Kutub alAlamiyah, 1996.

Hamka, Tafsir al-Azhar, juz XXX, Jakarta: Pustaka Panjimas, 1996.

Pawit M. Yusuf dan Yaya Suhendar, Pedoman Penyelenggaraan Perpustakaan Sekolah, Jakarta: Kencana, 2005.

Darmono, Manajemen dan Tata Kerja Perpustakaan Sekolah, Jakarta: Grasindo, 2004.

Peraturan Pemerintah Nomor 19 Nomor 19 Tahun 2005 tentang Standar Nasional Pendidikan Pasal 42 ayat 1 
Yatim Riyanto, Paradigma Baru Pembelajaran: Sebagai Referensi Bagi Guru Pendidik dalam Implementasi Pembelajaran Yang Efektif Dan Berkualitas, Jakarta: Kencana, 2009.

M. Quraish Shihab, Tafsir al-Misbah: Pesan, Kesan, dan Keserasian al-Qur'an, Volume: 1, Jakarta: Lentera Hati, 2004.

Imam Jalaluddin Abdurrahman bin Abi Bakr as-Suyuthi, Ad-Durru al-Mantsur fi Tafsir al-Ma'tsur, Beirut: Dar-al-Kutub al-'Alamiyah, 2000. 